\title{
Identification and analysis of phospholipid transfer protein polymorphisms and their association with marbling score in Hanwoo (Korean cattle)
}

\author{
J. Seong, J.D. Oh, H.K. Lee, G.J. Jeon and H.S. Kong \\ Genomic Informatics Center, Hankyong National University, \\ Anseong-si, Gyeonggi-do, Korea \\ Corresponding author: H.S. Kong \\ E-mail: kebinkhs@empal.com \\ Genet. Mol. Res. 12 (1): 731-737 (2013) \\ Received January 25, 2012 \\ Accepted November 27, 2012 \\ Published March 13, 2013 \\ DOI http://dx.doi.org/10.4238/2013.March.13.1
}

\begin{abstract}
Phospholipid transfer protein (PLTP) regulates highdensity lipoprotein metabolism. The gene encoding PLTP is located on bovine chromosome 13 . The objective of this study was to identify single nucleotide polymorphisms (SNPs) in the Hanwoo (Bos taurus coreanae) PLTP gene to detect novel mutations affecting economically important traits. Five SNPs were identified in the coding region(C7368T, G7453A, C9888T, and C9905T) and intron (A1750G). G7453A changes amino acid 362 of PLTP from alanine to threonine, and C9888T changes amino acid 491 of PLTP from proline to serine. Statistical analyses revealed that the G7453A and C9888T polymorphisms in the PLTP gene were significantly associated with marbling score $(\mathrm{P}<0.05)$. The relationship between haplotype and economic traits was analyzed and found to be significantly associated with marbling score $(\mathrm{P}<0.05)$. The results suggest that PLTP polymorphisms might be an important genetic influence on economic traits in Hanwoo.
\end{abstract}

Key words: Cattle; Hanwoo; SNP; Phospholipid transfer protein; Polymorphism 


\section{INTRODUCTION}

Hanwoo (Bos taurus coreanae) is a breed of cattle native to the Korean Peninsula and the Japanese Islands. It belongs to the European cattle (B. taurus) breeds (Mannen et al., 1998, 2004; Yum et al., 2004; Seong et al., 2012). Genetic improvement in the beef industry has become an important goal in Korea. The identification of the genes and polymorphisms underlying qualitative traits that produce beneficial economic traits might be crucial to the successful application of marker-assisted selection in commercial animal populations (Cheong et al., 2008). To aid in the early identification of beef cattle with superior genetic merits, researchers have identified qualitative trait loci (QTLs) for numerous economically important traits (McClure et al., 2010), and candidate gene analyses have been successfully conducted for these traits (Kim et al., 2000). The previous studies have used a genome scan for QTLs (McClure et al., 2010) and analyzed micromolar calciumactivated neutral protease 1 , calpastatin, and fatty acid synthase polymorphisms and their association with economic traits in cattle (Barendse et al., 2007).

Phospholipid transfer protein (PLTP, also called lipid transfer protein 2) has garnered considerable attention owing to its importance in the regulation of high-density lipoprotein (HDL) metabolism (Huuskonen et al., 2001). HDL represents a heterogeneous population of particles of various sizes, compositions, and electrophoretic mobilities (Albers et al., 1995). PLTP belongs to the lipopolysaccharide-binding/lipid transfer protein family, together with cholesteryl ester transfer protein, lipopolysaccharide-binding protein, and bactericidal/permeability-increasing protein (Bosse et al., 2005). Previous studies with mouse models have shown that PLTP has several key roles in lipoprotein metabolism, including the transfer of phospholipids from triglyceride-rich lipoproteins to HDL during lipolysis (Tall et al., 1985; Moerland et al., 2007).

In bovines, the PLTP gene is located on chromosome 13 and has a length of 10,135 bp and 15 exons (GenBank accession No. NC_007311). Chromosome 13 has multiple carcass QTLs with high levels of statistical support. In total, 1 carcass weight $(\mathrm{CW}), 3$ fat thickness, 3 marbling score (MS), 3 maternal milk, 4 ribeye muscle areas, 1 scrotal circumference, and 2 weaning weight QTLs have been detected in Angus (McClure et al., 2010). Two QTLs (BM6548 and AGLA232) near the PLTP QTL region have significant effects on MS (Schlapfer et al., 2002; McClure et al., 2010). These findings indicate that PLTP may influence economic traits. However, PLTP in Hanwoo has not been studied to date. The present study investigated the association of SNPs in the PLTP gene with economic traits in Hanwoo.

\section{MATERIAL AND METHODS}

\section{Cattle}

To explore SNPs, we used 1 SNP from 24 unrelated Korean native cattle. The SNP genotypes of 204 Korean native cattle tissue samples were used as material. The samples were collected as part of a progeny testing program at 2 stations in Korea (Korean Cattle Improvement Center, Agricultural Cooperative Federation; National Livestock Research Institute, Rural Development Administration). 
The weight at slaughter was recorded as $\mathrm{CW}$ at slaughter age. Backfat thickness and longissimus muscle dorsi area were measured at the 12th and 13th rib interface. MS was evaluated on a cross-section of the longissimus muscle at the 12th to 13th rib interface. MS was scored on a scale of 1-7 with 7 being associated with the most marbling.

\section{Detection of PLTP polymorphism and genotyping}

To identify SNPs in the PLTP gene, we designed 4 primer sets based on GenBank sequences (GenBank accession No. NC_007311). SNP genotyping of 24 samples was performed using direct sequencing with genomic DNA amplified with primers for each exon region (Table 1). Polymerase chain reaction (PCR) conditions were $94^{\circ} \mathrm{C}$ for 4 min and 35 cycles of $30 \mathrm{~s}$ at $94^{\circ} \mathrm{C}, 30 \mathrm{~s}$ at $56.4^{\circ} \mathrm{C}, 30 \mathrm{~s}$ at $72^{\circ} \mathrm{C}$, and a final step of $10 \mathrm{~min}$ at $72^{\circ} \mathrm{C}$ using a Peltier Thermal Cycler 200 (MJ Research, USA). The samples were sequenced using an ABI 3130 genomic analyzer (Applied Biosystems, USA). Sequence data were analyzed using the SeqMan II software (DNASTAR, USA). Three SNPs were selected to genotype the 204 samples using PCR restriction fragment length polymorphism analysis (Table 2 ).

\begin{tabular}{|c|c|c|c|}
\hline Primer name & Sequence $\left(5^{\prime} \rightarrow 3^{\prime}\right)$ & $\operatorname{Tm}\left({ }^{\circ} \mathrm{C}\right)$ & Expected frament size (bp) \\
\hline$\overline{\text { PLTP_1 }}$ & $\begin{array}{l}\text { ACCCATGGTCTTTAGCCACC } \\
\text { ATCCACTCTCCACTCCCAGG }\end{array}$ & 55 & 480 \\
\hline PLTP_2 & $\begin{array}{l}\text { TAGCTCCAAGCTGGAGTGACC } \\
\text { TCATAGCCAGGAAGTGGTGG }\end{array}$ & 54 & 332 \\
\hline PLTP_3 & $\begin{array}{l}\text { ACAGTCCTGGAGGGTTCTGG } \\
\text { CCTCCTTGACCCTCTGCATC }\end{array}$ & 55 & 390 \\
\hline PLTP_4 & $\begin{array}{l}\text { TACCACTCTGGTGCTCTGCC } \\
\text { GGGTACAGCTTAAAACCCCG }\end{array}$ & 55 & 385 \\
\hline
\end{tabular}

$\mathrm{Tm}=$ melting temperature.

\begin{tabular}{|c|c|c|c|c|c|}
\hline \multirow[t]{2}{*}{ SNPs } & \multirow[t]{2}{*}{ Restriction enzyme } & \multirow[t]{2}{*}{ Identification site } & \multicolumn{3}{|c|}{ Reaction condition } \\
\hline & & & Unit $(\mu \mathrm{L})$ & Temperature $\left({ }^{\circ} \mathrm{C}\right)$ & Time $(\mathrm{h})$ \\
\hline G7453A & AciI & 5'-C $\downarrow$ CG_C-3' & 0.6 & 37 & 4 \\
\hline C9888T & AgeI & 5'-A $\downarrow$ CCGG_T-3' & 0.6 & 37 & 4 \\
\hline
\end{tabular}

\section{Statistical analysis}

A linkage disequilibrium (LD) block of polymorphisms was tested using Haploview version 3.32 (Barrett et al., 2005). The haplotypes and their frequencies were calculated with the expectation-maximization algorithm (Stephens et al., 2001). Statistical analysis of the association among the genotypes (or haplotypes) and economic traits was performed with the least square method (generalized linear model procedure of the SAS software package, SAS Institute, USA) using the following statistical linear model: 


$$
\mathrm{Y}_{\mathrm{ijk} \mathrm{k}}=\mu+\mathrm{YS}_{\mathrm{i}}+\mathrm{P}_{\mathrm{j}}+\mathrm{M}_{\mathrm{k}}+\mathrm{e}_{\mathrm{ijk} \mathrm{k}}
$$

where $Y_{i j k l}$ is the observation of the carcass traits; $\mu$ is the overall mean for each trait; $Y S_{i}$ is the effect of the $i^{t \text { th }}$ year and season of calving; $P_{j}$ is the fixed effect of the $j^{\text {th }}$ parity; $M_{k}$ is the fixed effect of the $k^{\text {th }}$ SNP genotype (or haplotype), and $e_{i j k l}$ is the random residual effect.

\section{RESULTS AND DISCUSSION}

Direct DNA sequencing identified 5 polymorphisms in the PLTP gene: 4 in coding exons (C7368T, G7453A, C9888T, and C9905T) and 1 in an intron (A1750G). A1750G, G7453A, and C9888T are new SNPs. The locations, allele frequency, and genotype frequency for Hanwoo $(\mathrm{N}=24)$ are shown in Figure 1A and Table 3. The A1750G frequency for allele A was higher than that for allele $\mathrm{G}$, and 0.80 and 0.20 displayed the AA and AG genotypes, respectively. The G7453A frequency for allele A was higher than that for allele $G$, and 0.23 , 0.63 , and 0.14 displayed the GG, GA, and AA genotypes, respectively. The C9888T frequency for allele $\mathrm{C}$ was higher than that for the $\mathrm{T}$ allele. Moreover, $0.25,0.63$, and 0.12 displayed the $\mathrm{CC}, \mathrm{CT}$, and TT genotypes, respectively.

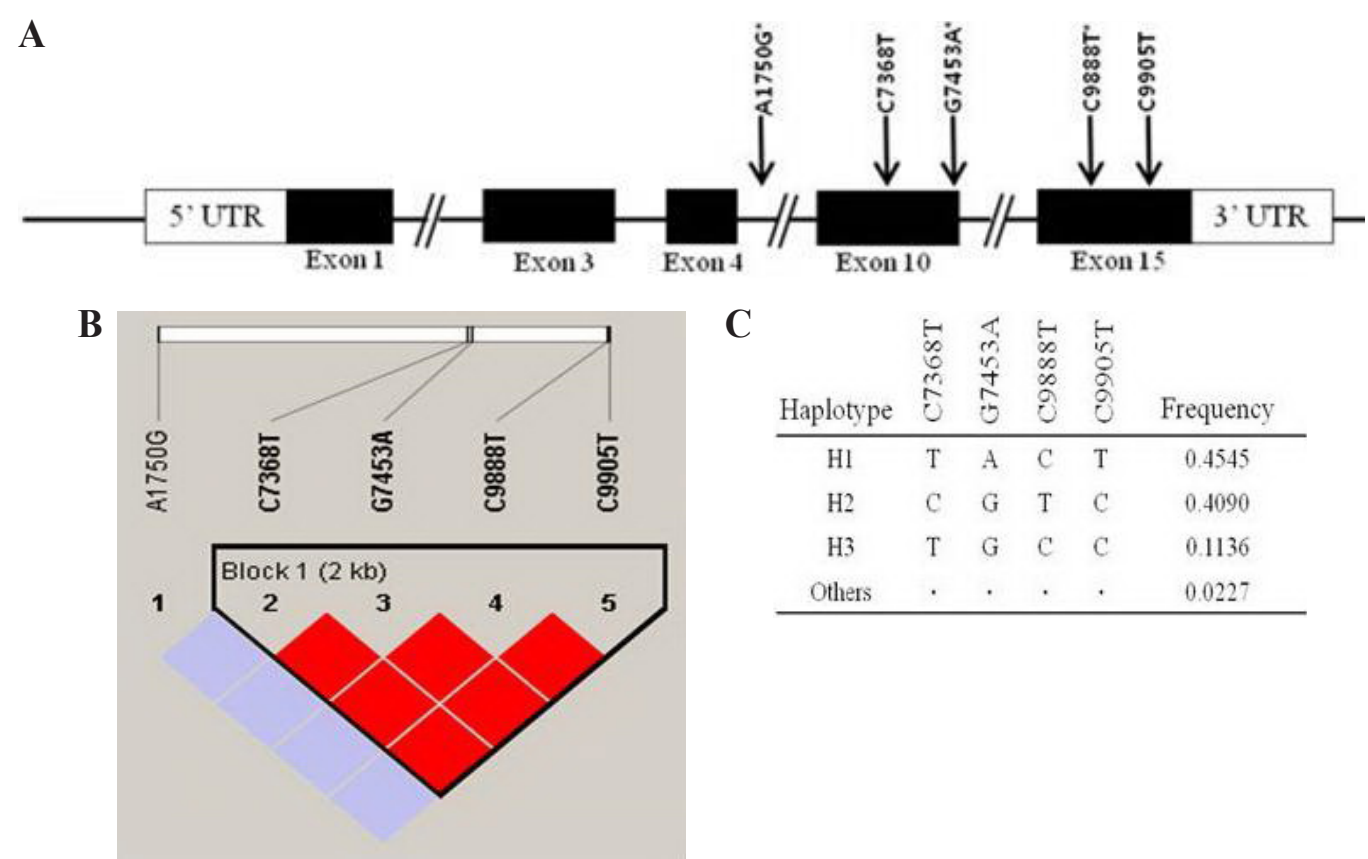

Figure 1. Gene map, haplotypes, and linkage disequilibrium (LD) coefficients in phospholipid transfer protein (PLTP). A. Gene map and polymorphisms in PLTP on chromosome 13. The coding exon is marked by filled blocks, and 5'- and 3'-untranslated regions by open blocks. Asterisks (*) indicate new SNPs. B. LD blocks among PLTP polymorphisms are shown using Haploview. The color code on the Haploview plot follows the standard color scheme: shades of red $\left(\left|\mathrm{D}^{\prime}\right|<1, \mathrm{LOD} \geq 2\right)$; bright purple $\left(\left|\mathrm{D}^{\prime}\right|<1, \mathrm{LOD}<2\right)$. C. Haplotypes in PLTP; haplotypes with frequency $>0.1$ are presented. 
Table 3. Genotype and allele frequencies of polymorphisms of phospholipid transfer protein in Hanwoo $(\mathrm{N}=24)$.

\begin{tabular}{|c|c|c|c|c|c|c|c|}
\hline \multirow[t]{2}{*}{ SNP } & \multirow[t]{2}{*}{ Position } & \multirow[t]{2}{*}{ AA change } & \multicolumn{3}{|c|}{ Genotype frequency } & \multicolumn{2}{|c|}{ Allele frequency } \\
\hline & & & 11 & 12 & 22 & & \\
\hline A1750G* & Intron 5 & & $\mathrm{AA}(0.80)$ & $\mathrm{AG}(0.20)$ & GG $(0.00)$ & $\mathrm{A}(0.90)$ & $\mathrm{G}(0.10)$ \\
\hline C7368T & Exon 10 & Synonymous & $\mathrm{CC}(0.18)$ & CT (0.45) & TT $(0.37)$ & $\mathrm{C}(0.41)$ & $\mathrm{T}(0.59)$ \\
\hline G7453A* & Exon 10 & $\mathrm{Ala} \rightarrow \mathrm{Thr}$ & $\mathrm{GG}(0.23)$ & $\mathrm{GA}(0.63)$ & AA $(0.14)$ & $\mathrm{G}(0.54)$ & $\mathrm{A}(0.46)$ \\
\hline C9888T* & Exon 15 & Pro $\rightarrow$ Ser & $\mathrm{CC}(0.25)$ & CT (0.63) & TT $(0.12)$ & $\mathrm{C}(0.56)$ & $\mathrm{T}(0.44)$ \\
\hline C9905T & Exon 15 & Synonymous & $\mathrm{CC}(0.37)$ & CT (0.46) & $\mathrm{TT}(0.17)$ & $\mathrm{C}(0.60)$ & $\mathrm{T}(0.40)$ \\
\hline
\end{tabular}

*New SNP.

C7368T and C9905T were synonymous mutations, whereas G7453A and C9888T were missense mutations. G7453A changes amino acid 362 of PLTP from alanine to threonine. C9888T changes amino acid 491 of PLTP from proline to serine. Among the polymorphisms identified, 5 were selected for larger-scale genotyping. The minor allele frequencies of genotyped polymorphisms were 0.2 (A1750G), 0.18 (C7368T), 0.14 (G7453A), 0.12 (C9888T), and 0.17 (C9905T; see Table 3). Pairwise LD analysis with the 4 polymorphisms showed that the PLTP gene could be parsed into $1 \mathrm{LD}$ block - the 8.3-kb region spanning from intron 5 to exon 15 (Figure 1B). Three major haplotypes (frequency $>0.1$ ) were constructed (Figure 1C) using these 4 polymorphisms. The T-A-C-T type $(0.4545)$ was the highest, followed by the C-G-T-C type (0.4090) and the T-G-C-C type (0.1136).

The missense mutation identified in the polymorphism using the PCR restriction fragment length polymorphism technique presented a correlation between genotype and economic traits. The PLTP gene G7453A locus was restriction digested by AciI to produce fragments of 176, 109, and $67 \mathrm{bp}$. The C9888T locus was restriction digested with AgeI to produce fragments of 415, 248, and $167 \mathrm{bp}$ (see Table 2).

Estimated PLTP gene allele and genotype frequencies for Hanwoo $(\mathrm{N}=204)$ are shown in Table 4. The G7453A frequency for allele A was the same as that for allele G. Respectively, 0.26, 0.48, and 0.26 displayed the GG, GA, and AA genotypes. The C9888T frequency for allele $\mathrm{C}$ was higher than that for allele $\mathrm{T}$. The $\mathrm{CC}, \mathrm{CT}$, and TT genotypes were displayed in $0.46,0.50$, and 0.04 , respectively.

Table 4. Genotype and allele frequencies of SNPs of phospholipid transfer protein in Hanwoo (N = 204).

\begin{tabular}{|c|c|c|c|c|c|c|c|}
\hline \multirow[t]{2}{*}{ SNP } & \multirow[t]{2}{*}{ Position } & \multirow[t]{2}{*}{ AA change } & \multicolumn{3}{|c|}{ Genotype frequency } & \multicolumn{2}{|c|}{ Allele frequency } \\
\hline & & & 11 & 12 & 22 & & \\
\hline G7453A & Exon 10 & $\mathrm{Ala} \rightarrow \mathrm{Thr}$ & GG (0.26) & $\mathrm{GA}(0.48)$ & $\mathrm{AA}(0.26)$ & $\mathrm{G}(0.5)$ & $\mathrm{A}(0.5)$ \\
\hline C9888T & Exon 15 & Pro $\rightarrow$ Ser & $\mathrm{CC}(0.46)$ & CT $(0.50)$ & TT $(0.04)$ & $\mathrm{C}(0.71)$ & $\mathrm{T}(0.29)$ \\
\hline
\end{tabular}

To investigate the effects of SNPs, we analyzed the association of PLTP genotypes to determine the effects on variations in economic traits. Both the G7453A and the C9888T SNPs were associated with a significant effect on MS. The GG genotype displayed a higher MS than that of genotype GA in SNP marker G7453A $(\mathrm{P}<0.05)$, and the CC genotype displayed a higher MS than that of genotype CT in the SNP marker C9888T $(\mathrm{P}<0.05$; Table 5). 


\begin{tabular}{|c|c|c|c|c|c|}
\hline \multirow[t]{2}{*}{ SNP } & \multirow[t]{2}{*}{ Trait } & \multicolumn{3}{|c|}{ Genotype } & \multirow[t]{2}{*}{$\mathrm{P}$} \\
\hline & & 11 & 12 & 22 & \\
\hline \multirow[t]{4}{*}{ G7453A } & $\mathrm{CW}(\mathrm{kg})$ & $\mathrm{GG}(424.7 \pm 6.02)$ & $\mathrm{GA}(415.5 \pm 4.51)$ & $\mathrm{AA}(405.98 \pm 6.02)$ & 0.0908 \\
\hline & $\operatorname{LMA}\left(\mathrm{cm}^{2}\right)$ & $\mathrm{GG}(91.2 \pm 1.43)$ & GA $(89.4 \pm 10.7)$ & $\mathrm{AA}(90.29 \pm 1.43)$ & 0.6156 \\
\hline & $\mathrm{BF}(\mathrm{cm})$ & GG $(13.5 \pm 0.73)$ & GA $(11.8 \pm 0.55)$ & $\mathrm{AA}(12.24 \pm 0.73)$ & 0.1929 \\
\hline & MS & $\mathrm{GG}(6.11 \pm 0.39)$ & $\mathrm{GA}(4.57 \pm 0.29)$ & $\mathrm{AA}(5.88 \pm 0.39)$ & 0.0021 \\
\hline \multirow[t]{4}{*}{ C9888T } & $\mathrm{CW}(\mathrm{kg})$ & $\mathrm{CC}(419.8 \pm 4.58)$ & CT $(410.1 \pm 4.39)$ & $\mathrm{TT}(431.50 \pm 15.71)$ & 0.1843 \\
\hline & LMA $\left(\mathrm{cm}^{2}\right)$ & $\mathrm{CC}(91.5 \pm 1.07)$ & $\mathrm{CT}(88.6 \pm 1.03)$ & TT $(93.25 \pm 3.69)$ & 0.1141 \\
\hline & $\mathrm{BF}(\mathrm{cm})$ & $\mathrm{CC}(12.3 \pm 0.56)$ & $\mathrm{CT}(12.4 \pm 0.54)$ & $\mathrm{TT}(12.12 \pm 1.93)$ & 0.9747 \\
\hline & MS & $\mathrm{CC}(5.96 \pm 0.29)$ & CT $(4.6 \pm 0.28)$ & $\mathrm{TT}(6.25 \pm 1.01)$ & 0.0051 \\
\hline
\end{tabular}

$\overline{\mathrm{CW}}=$ carcass weight; $\mathrm{LMA}=$ longissimus muscle area; $\mathrm{BF}=$ backfat thickness; $\mathrm{MS}=$ marbling score.

In this study, the PLTP gene was analyzed for the haplotype of G7453A and C9888G in Hanwoo $(\mathrm{N}=204)$. The haplotype analysis revealed 4 types that verified G-C, A-C, A-T, and G-T. The G-C type (0.3885) was the highest, followed by the A-C type (0.3222), A-T type (0.1777), and G-T type (0.1114; Table 6). The relationship between haplotype and economic traits was also analyzed (Table 7). A significant effect on MS was found $(\mathrm{P}<0.05)$. The H1 type $(425.9 \pm 3.92)$ was the highest in $\mathrm{CW}$, and the $\mathrm{H} 4$ type $(5.96 \pm 0.56)$ was the highest in MS. This result resembled the significant association of SNP markers G7453A and C9888T with MS. Previous studies have reported that chromosome 13 has multiple carcass QTLs with high levels of statistical support. Three MS QTLs have been detected in Angus (McClure et al., 2010). Two of the QTLs (BM6548 and AGLA232) are near the PLTP QTL region and significantly influence MS (Schlapfer et al., 2002; McClure et al., 2010). The results provide evidence that the PLTP gene is a candidate gene for carcass traits.

Table 6. Haplotype structure and frequency in two major phospholipid transfer protein polymorphisms.

\begin{tabular}{lccc}
\hline Haplotype & G4753A & C9888T & Frequency \\
\hline H1 & G & C & 0.3885 \\
H2 & A & C & 0.3222 \\
H3 & A & T & 0.1777 \\
H4 & G & T & 0.1114 \\
\hline
\end{tabular}

\begin{tabular}{|c|c|c|c|c|c|}
\hline Trait & H1 & $\mathrm{H} 2$ & H3 & H4 & $\mathrm{P}$ \\
\hline $\mathrm{CW}$ & $425.9 \pm 3.92$ & $410.5 \pm 4.09$ & $415.1 \pm 7.14$ & $422.0 \pm 8.36$ & 0.0538 \\
\hline LMA & $90.4 \pm 0.79$ & $90.5 \pm 0.98$ & $89.0 \pm 1.10$ & $89.9 \pm 2.02$ & 0.7294 \\
\hline $\mathrm{BF}$ & $12.3 \pm 0.40$ & $12.3 \pm 0.50$ & $11.7 \pm 0.56$ & $14.81 \pm 1.04$ & 0.0762 \\
\hline MS & $5.29 \pm 0.21$ & $5.84 \pm 0.27$ & $4.56 \pm 0.30$ & $5.96 \pm 0.56$ & 0.0117 \\
\hline
\end{tabular}

For abbreviation, see legend to Table 5.

The present study identified SNPs of the PLTP in Korean cattle. C7368T and C9905T were found to be synonymous mutations, whereas C7368T (Ala362Thr) and C9888T (Pro491Ser) were identified as missense mutations. Statistical analysis revealed that 2 polymorphisms (G7453A and C9888G) in the coding region were significantly associated with the important carcass trait MS in Hanwoo. The results suggested that polymorphisms in PLTP might be important genetic factors influencing economic traits in Hanwoo. 


\section{ACKNOWLEDGMENTS}

Research supported by a grant from the Next-Generation BioGreen 21 Program (\#PJ008196), Rural Development Administration, Republic of Korea.

\section{REFERENCES}

Albers JJ, Wolfbauer G, Cheung MC, Day JR, et al. (1995). Functional expression of human and mouse plasma phospholipid transfer protein: effect of recombinant and plasma PLTP on HDL subspecies. Biochim. Biophys. Acta 1258: 27-34.

Barendse W, Harrison BE, Hawken RJ, Ferguson DM, et al. (2007). Epistasis between calpain 1 and its inhibitor calpastatin within breeds of cattle. Genetics 176: 2601-2610.

Barrett JC, Fry B, Maller J and Daly MJ (2005). Haploview: analysis and visualization of LD and haplotype maps. Bioinformatics 21: 263-265.

Bosse Y, Bouchard L, Despres JP, Bouchard C, et al. (2005). Haplotypes in the phospholipid transfer protein gene are associated with obesity-related phenotypes: the Quebec Family Study. Int. J. Obes. 29: 1338-1345.

Cheong HS, Yoon DH, Park BL, Kim LH, et al. (2008). A single nucleotide polymorphism in CAPN1 associated with marbling score in Korean cattle. BMC Genet. 9: 33.

Huuskonen J, Olkkonen VM, Jauhiainen M and Ehnholm C (2001). The impact of phospholipid transfer protein (PLTP) on HDL metabolism. Atherosclerosis 155: 269-281.

Kim KS, Larsen N, Short T, Plastow G, et al. (2000). A missense variant of the porcine melanocortin-4 receptor (MC4R) gene is associated with fatness, growth, and feed intake traits. Mamm. Genome 11: 131-135.

Mannen H, Tsuji S, Loftus RT and Bradley DG (1998). Mitochondrial DNA variation and evolution of Japanese black cattle (Bos taurus). Genetics 150: 1169-1175.

Mannen H, Kohno M, Nagata Y, Tsuji S, et al. (2004). Independent mitochondrial origin and historical genetic differentiation in North Eastern Asian cattle. Mol. Phylogenet. Evol. 32: 539-544.

McClure MC, Morsci NS, Schnabel RD, Kim JW, et al. (2010). A genome scan for quantitative trait loci influencing carcass, post-natal growth and reproductive traits in commercial Angus cattle. Anim. Genet. 41: 597-607.

Moerland M, Anghelescu N, Samyn H, van Haperen R, et al. (2007). Inducible expression of phospholipid transfer protein (PLTP) in transgenic mice: acute effects of PLTP on lipoprotein metabolism. Transgenic Res. 16: 503-513.

Schlapfer J, Stahlberger-Saitbekova N, Comincini S, Gaillard C, et al. (2002). A higher resolution radiation hybrid map of bovine chromosome 13. Genet. Sel. Evol. 34: 255-267.

Seong J, Suh DS, Park KD, Lee HK, et al. (2012). Identification and analysis of MC4R polymorphisms and their association with economic traits of Korean cattle (Hanwoo). Mol. Biol. Rep. 39: 3597-3601.

Stephens M, Smith NJ and Donnelly P (2001). A new statistical method for haplotype reconstruction from population data. Am. J. Hum. Genet. 68: 978-989.

Tall AR, Krumholz S, Olivecrona T and Deckelbaum RJ (1985). Plasma phospholipid transfer protein enhances transfer and exchange of phospholipids between very low density lipoproteins and high density lipoproteins during lipolysis. J. Lipid Res. 26: 842-851.

Yum SS, Suh JY, Kim KC, Woo SO, et al. (2004). Genetic relationship of Korean cattle (Hanwoo) based on nucleotide variation of mitochondrial D-loop region. Korean J. Genet. 26: 297-307. 